Acta Agroph., 2019, 26(1), 37-45

doi: $10.31545 /$ aagr/108535

\title{
BIOSTIMULATORS AS A FACTOR AFFECTING THE DRY MATTER YIELD AND STARCH CONTENT OF EDIBLE POTATO TUBERS
}

\author{
Iwona Teresa Mystkowska 리 \\ Department of Agriculture, Pope John Paul II State School of Higher Education \\ Sidorska 95/97, 21-500, Biała Podlaska, Poland \\ e-mail: imystkowska@op.pl
}

\begin{abstract}
The experiment was carried out as a two-factor experiment in a split-plot system, repeated three times within the years 2015-2017 on an individual farm. The following factors were examined: I - three varieties of edible potato: Honorata, Jelly, Tajfun, and II - four types of biostimulators used in three periods (beginning of flowering, full flowering and after flowering of the plants): Kelpak SL ${ }^{\circledR}$, dosage $0.20 \mathrm{mg} \mathrm{l}^{-1}$, Titanit ${ }^{\circledR}$, dosage $0.20 \mathrm{mg} \mathrm{l}^{-1}$, GreenOk ${ }^{\circledR}$, dosage $0.20 \mathrm{mg} \mathrm{l}^{-1}$, BrunatneBio Złoto $\AA$, dosage $0.20 \mathrm{mg} \mathrm{l}^{-1}$ and a control variant (without the use of biostimulators). The aim of the study was to determine the effect of biostimulators on the dry matter yield and starch yield of edible potato tubers. The content of dry matter was determined by means of a dry weight method. The starch content was determined using the Reimann hydrostatic balance. Dry matter yield and starch yield were calculated as a product of the total yield and the content of individual components. The results obtained were statistically analysed with the use of the analysis of variance. The use of biostimulators in the experiment increased the amount of dry matter yield and the yield of edible potato tuber starch as compared with the control plot. The reaction of the different varieties to the biostimulators used was diverse. The highest dry matter yield and starch yield was produced by the Jelly variety. The BrunatneBio Złoto biostimulator significantly increased the dry matter yield and starch yield as compared with the control variant. The Jelly variety produced the highest dry matter yield and starch yield, while the Honorata variety reacted with a decrease in the yield in relation to the variant in which the biostimulator was not used. The diverse climatic conditions prevailing during the growing season in the years when the research was conducted influenced the yield of dry matter and starch.

Keyw ord s: yield, variants, BrunatneBio Złoto ${ }^{\circledR}$, Kelpak SL ${ }^{\circledR}$, Titanit ${ }^{\circledR}$, GreenOk ${ }^{\circledR}$
\end{abstract}

\section{INTRODUCTION}

Potato crops intended for human consumption should be characterized by a high tuber yield with the highest quality parameters (Sawicka 2016). For this purpose, in addition to pesticides, a number of appropriate preparations such as biostimulators are used (Maciejewski et al. 2007). Biostimulators are usually used for prophylactic 
or interventional treatments. The most important function fulfilled by foliar nutrition is the interventional replenishment of the shortage of nutrients during the growing season caused by e.g. intensive plant development, drought, or agrotechnical errors (Bienia et al. 2018). This activity consists of stimulating the growth of leaves, stalks and roots. A biostimulator used when the plants are still healthy should change their metabolism in such a way that they become stronger and more resistant, for example, to pathogen attack or drought (Czeczko and Mikos-Bielak 2004). Harasimowicz-Herman, Borowska (2006), and Budzyński et al. (2008) emphasize that the use of biostimulators is beneficial when plants are grown under unfavourable conditions, as they allow for the correction of poor nutrition in plants (Fageria et al. 2009, Fernandez et al. 2013, Singh et al. 2013). The basic component of potato tubers is dry matter. Its amount depends on the variety and the environment, which includes biotic factors that are beyond human control (climate, soil), as well as abiotic factors, i.e. agrotechnical treatments and storage (Boguszewska 2007, Kołodziejczyk and Szmigiel 2012, Sawicka and Pszczółkowski 2017, Zgórska and Grudzińska 2012). The content of dry matter in edible varieties of potato tubers entered in the National Register in Poland varies from 17.3 to $25.6 \%$ (Boguszewska et al. 2011). The main component of dry matter is starch, which accounts for 75 to $80 \%$ of its content. In currently registered edible varieties, its content ranges from 11.0 to $18.3 \%$ (Boguszewska et al. 2011). Starch content depends on the genetic factors of a given variety, growing conditions, as well as the weather during vegetation (Wierzbicka 2012, Zgórska and Grudzińska 2012). The research hypothesis of the study is that the use of biostimulators can increase dry matter yield and starch yield. Because there are only a handful of studies concerning the beneficial effect of using biostimulators on the amount of dry matter yield and starch yield, and due to its relevance to agricultural practice, research has been undertaken to determine the impact of biostimulators on these determinants.

\section{MATERIAL AND METHODS}

The research was based on a 3-year (2015-2017) field experiment conducted on an individual farm in Międzyrzec Podlaski ( $\left.51^{\circ} 59^{\prime} \mathrm{N} 22^{\circ} 47^{\prime} \mathrm{E}\right)$. It was decided to conduct the experiment three times using the randomized blocks (split-plot) system, on a very good example of rye complex soil, bonitation class IVa. In individual years of research, the soil differed in the content of organic matter and digestible macroelements. In 2015 and 2016, the soil was characterized by a slightly acid reaction, and in the last year of research the reaction was alkaline. The content of organic matter ranged from 15.0 to $18.7 \mathrm{~g} \mathrm{~kg}^{-1}$. The content of assimilable phosphorus $(\mathrm{P})$ varied from high to very high, potassium $(\mathrm{K})$ from medium to very high, and the content of magnesium $(\mathrm{Mg})$ was high. The first factor consisted of three 
varieties of edible potato: Honorata, Jelly, Tajfun, and the second one of four types of biostimulators used in three periods (beginning of flowering, full flowering and after the flowering of the plants):

1. Control variant - without the use of biostimulators, sprayed with distilled water,

2. Kelpak ${ }^{\circledR S L}$ biostimulator (active substance - Ecklonia maxima algae extract), containing plant hormones: auxins $-11 \mathrm{mg} \mathrm{l}^{-1}$, and cytokinins $-0.031 \mathrm{mg}^{-1}$, dosage $0.20 \mathrm{mg} \mathrm{l}^{-1}$,

3. Tytanit $\AA$ biostimulator (active substance - titanium), dosage $0.201 \mathrm{ha}^{-1}$,

4. GreenOk ${ }^{\circledR}$ biostimulator (active substances - humic substances $20 \mathrm{~g}^{-1}$ ), dosage $0.201 \mathrm{ha}^{-1}$.

5. BrunatneBio Złoto biostimulator (active substances - plant hormones: auxins $-0.06 \mathrm{mg} \mathrm{l}^{-1}$ and cytokinins $-12 \mathrm{mg} \mathrm{l}^{-1}$ ), dosage $0.201 \mathrm{ha}^{-1}$.

Winter wheat was used as a forecrop for potatoes in particular years of the research. After the forecrop harvest, a set of post-harvest crops was grown. In the autumn of each year preceding planting, natural fertilization in the form of manure was applied in the amount of $25.0 \mathrm{t} \mathrm{ha}^{-1}$, as well as mineral fertilization with phosphorus-potassium in the amount of $\mathrm{P}-44.0\left(100 \mathrm{P}_{2} \mathrm{O}_{5} \cdot 0.44\right) \mathrm{kg} \mathrm{ha}^{-1}$ (Lubofos for potatoes $7 \%$ ) and $\mathrm{K}-124.5\left(150 \mathrm{~K}_{2} \mathrm{O} \cdot 0.83\right) \mathrm{kg} \mathrm{ha}^{-1}$ (Lubofos for potatoes $25 \%$ ). These fertilizers were ploughed with pre-winter ploughing. Nitrogen fertilizers were sown in spring in the amount of $\mathrm{N}$ equivalent to $100 \mathrm{~kg} \mathrm{ha}^{-1}$ (nitro-chalk 27\%) and mixed with the soil using a cultivator. Potatoes were planted manually relative to the indicator at a distance of $67.5 \times 37 \mathrm{~cm}$, in the third decade of April $(2015,2016$, 2017). Each plot with an area of $15 \mathrm{~m}^{2}$ accounted for five ridges. Cultivation and care treatments were carried out in accordance with the requirements of the appropriate agrotechnics and methodological assumptions of the experiment. The harvest was carried out when tubers were fully ripened, in the first decade of September. Each year, just before the harvest, tubers from ten randomly selected plants were dug out (from two middle rows, excluding marginal plants), for which the yield structure was determined according to the transverse fraction $<35 \mathrm{~mm}, 36-50,51-60$, $>60 \mathrm{~mm}$. The total potato yield was calculated on the basis of the mass of tubers harvested from the plot surface added to the mass of previously collected samples. The starch content was determined using a Reimann hydrostatic balance. Subsequently, the qualitative analysis of potato tubers was carried out, the dry matter content of a fresh mass of tubers was determined using a dry weight method, by drying them at $65-70^{\circ} \mathrm{C}$, followed by drying at $105^{\circ} \mathrm{C}$ to obtain a constant weight.

The results of the study were subjected to statistical analysis using the analysis of variance, and the significance of differences was assessed using the Tukey test at the significance level of $\mathrm{P}=0.05$. Statistical calculations were performed in Excel using the authors own algorithm based on the split-plot mathematical model with two factors (Trętowski and Wójcik 1988). 


$$
Y i j l=m+a i+g l+e / 1 / i l+b j+a b i j+e / 2 / i j l
$$

Where: Yijl - value of the characteristic researched; i level of A (cultivars), $j$ - level of B (cultivars) in the $1^{\text {st }}$ block (replication), $\mathrm{m}$ - experimental mean, ai - effect of i-level of A (cultivars), gl - effect of the 1st replication, e/1/il - random effect of A (cultivars) with replications, bj - effect of j-level of B (biostimulants), abij effect of interaction of A (cultivars) and B (biostimulants), $\mathrm{e}_{/ 2 / \mathrm{ijl}}-$ random effect II

The climatic conditions prevailing during the years of the study are shown in Table 1. In the growing season of 2015 , the average air temperature was $15.2^{\circ} \mathrm{C}$, which was higher by $0.2^{\circ} \mathrm{C}$ than the multi-year period average, and precipitation amounted to $295.1 \mathrm{~mm}$. The highest average air temperature was recorded in 2016 - it amounted to $15.8^{\circ} \mathrm{C}$, which was higher than the multi-year period average by $0.8^{\circ} \mathrm{C}$, while this year was characterized by the lowest precipitation sum -200.9 $\mathrm{mm}$, lower by $134.5 \mathrm{~mm}$ than for the multi-year period sum. The highest amount of rainfall was recorded in the growing season of $2017-324.4 \mathrm{~mm}$, and the lowest average air temperature: $14.6^{\circ} \mathrm{C}$.

Table 1. Precipitation and temperature of air during potato vegetation by the Meteorological Station Zawady (2015-2017)

\begin{tabular}{|c|c|c|c|c|c|c|c|}
\hline \multirow{2}{*}{ Years } & \multicolumn{7}{|c|}{ Months } \\
\hline & IV & $\mathrm{V}$ & VI & VII & VIII & IX & IV-IX \\
\hline \multicolumn{8}{|c|}{ Rainfalls (mm) } \\
\hline 2015 & 30.0 & 100.2 & 43.3 & 62.6 & 11.9 & 47.1 & 295.1 \\
\hline 2016 & 28.7 & 54.8 & 36.9 & 35.2 & 31.7 & 13.6 & 200.9 \\
\hline 2017 & 59.6 & 49.5 & 57.9 & 23.6 & 54.7 & 80.1 & 325.4 \\
\hline$(1996-2010)$ & 33.6 & 58.3 & 59.6 & 57.5 & 59.9 & 42.3 & 335.4 \\
\hline \multicolumn{8}{|c|}{ Temperature $\left({ }^{\circ} \mathrm{C}\right)$} \\
\hline 2015 & 8.2 & 12.3 & 16.5 & 18.7 & 21.0 & 14.5 & 15.2 \\
\hline 2016 & 19.1 & 15.1 & 18.4 & 19.1 & 18.0 & 14.9 & 15.8 \\
\hline 2017 & 6.9 & 13.9 & 17.8 & 16.9 & 18.4 & 13.9 & 14.6 \\
\hline$(1996-2010)$ & 8.0 & 13.5 & 17.0 & 19.7 & 18.5 & 13.5 & 15.0 \\
\hline
\end{tabular}

\section{TEST RESULTS AND DISCUSSION}

The research shows that the yield of dry matter and starch depended to large extent on the potato tuber varieties grown (Tabs 2-3). The volume of dry matter yield and starch yield were determined as resultants of the tuber yield (Mystkowska 2018) and concentrations of the listed components. On the basis of the conducted tests, a significantly higher dry matter yield and starch yield were found in the case of the Jelly variety, a lower yield of individual nutrients was noted in the Tajfun variety, and the lowest one was produced by the Honorata variety. The content of dry matter and starch in potato tubers is a varietal feature but with a proper yield size, varieties with 
a lower content of dry matter and starch may produce yields of individual potato nutrients at a comparable or higher level than the varieties of lower yield, yet with a higher content of these components (Krzysztofik 2009). The results of our own research confirmed the observations of Żołnowski (2013), Gugała et al. (2017), and Pszczółkowski and Sawicka (2018). The biostimulators used had a significant impact on the discussed features, however, there was a tendency to increase the dry matter yield of tubers and starch yield under the influence of the preparations used, as compared with the control variant. The largest significant increase in these components occurred in tubers harvested from plots sprayed with the BrunatneBio Złoto biostimulator (variant 5). The dry matter yield of this variant amounted to $11.3 \mathrm{tha}^{-1}$, while the yield of starch was $7.3 \mathrm{tha}^{-1}$ (Tabs 2,3). The hydrothermal conditions prevailing during the years of the study were also a factor that significantly modified the content of the dry matter yield and starch yield. The highest dry matter yield and starch yield was obtained in 2017, in which the months of harvesting (July and August) were predominated by average moisture conditions and favourable air temperatures (Tab. 1).

Table 2. Yield of dry mass of potato tubers depending on the types of biostimulants used, varieties and years $\left(\mathrm{t} \mathrm{ha}^{-1}\right)$

\begin{tabular}{|c|c|c|c|c|}
\hline \multirow{2}{*}{ Variants } & \multicolumn{3}{|c|}{ Years } & \multirow{2}{*}{ Mean } \\
\hline & 2015 & 2016 & 2017 & \\
\hline \multicolumn{5}{|c|}{ Honorata } \\
\hline 1. Control variant & 8.4 & 9.0 & 10.9 & 9.4 \\
\hline 2. Kelpak SL & 9.1 & 9.2 & 11.2 & 9.8 \\
\hline 3. Tytanit & 9.3 & 9.4 & 12.2 & 10.3 \\
\hline 4. GreenOK & 9.7 & 9.5 & 11.8 & 10.3 \\
\hline 5. BrunatneBio Złoto & 9.5 & 10.0 & 11.6 & 10.4 \\
\hline Mean & 9.2 & 9.4 & 11.5 & $10.0 \mathrm{c}$ \\
\hline \multicolumn{5}{|c|}{ Jelly } \\
\hline 1. Control variant & 10.7 & 11.9 & 13.0 & 11.9 \\
\hline 2. Kelpak SL & 11.3 & 12.1 & 13.2 & 12.2 \\
\hline 3. Tytanit & 11.7 & 12.3 & 13.2 & 12.4 \\
\hline 4. GreenOk & 11.6 & 12.3 & 13.4 & 12.4 \\
\hline 5. BrunatneBio Złoto & 11.5 & 12.4 & 13.6 & 12.5 \\
\hline Mean & 11.4 & 12.2 & 13.3 & $12.3 \mathrm{a}$ \\
\hline \multicolumn{5}{|c|}{ Tajfun } \\
\hline 1. Control variant & 9.3 & 10.1 & 10.4 & 9.9 \\
\hline 2. Kelpak SL & 9.7 & 10.5 & 10.6 & 10.3 \\
\hline 3. Tytanit & 10.2 & 10.5 & 11.1 & 10.6 \\
\hline 4. GreenOk & 10.1 & 10.8 & 11.4 & 10.8 \\
\hline 5. BrunatneBio Złoto & 10.2 & 11.0 & 11.3 & 10.8 \\
\hline Mean & 9.9 & 10.6 & 11.0 & $10.5 b$ \\
\hline \multicolumn{5}{|c|}{ Mean for varieties } \\
\hline 1. Control variant & $9.5 \mathrm{E}$ & $10.4 \mathrm{CD}$ & $11.5 \mathrm{AB}$ & $10.5 \mathrm{c}$ \\
\hline 2. Kelpak Sl & 10.0DE & $10.6 \mathrm{CD}$ & $11.7 \mathrm{AB}$ & $10.8 \mathrm{c}$ \\
\hline 3. Tytanit & $10.4 \mathrm{CD}$ & $10.7 \mathrm{CD}$ & $12.2 \mathrm{~A}$ & $11.1 \mathrm{a}$ \\
\hline 4. GreenOk & $10.5 \mathrm{CD}$ & $10.9 \mathrm{BC}$ & $12.2 \mathrm{~A}$ & $11.2 \mathrm{ab}$ \\
\hline 5. BrunatneBio Złoto & $10.4 \mathrm{C}$ & 11.2BC & $12.2 \mathrm{~A}$ & $11.3 \mathrm{ab}$ \\
\hline Mean & $10.2 \mathrm{c}$ & $10.8 \mathrm{~b}$ & $12.0 \mathrm{a}$ & $11.0 \mathrm{a}$ \\
\hline
\end{tabular}

Means with the same letters do not differ significantly at $\mathrm{P} \leq 0.05$ 
Table 3. Potato starch yields of potato tubers depending on the types of biostimulants used, varieties and years $\left(\mathrm{t} \mathrm{ha}^{-1}\right)$

\begin{tabular}{|c|c|c|c|c|}
\hline \multirow{2}{*}{ Variants } & \multicolumn{3}{|c|}{ Years } & \multirow{2}{*}{-Mean } \\
\hline & 2015 & 2016 & 2017 & \\
\hline & Honorats & & & \\
\hline 1. Control variant & 6.0 & 5.9 & 6.5 & 6.1 \\
\hline 2. Kelpak SL & 6.4 & 6.1 & 6.9 & 6.5 \\
\hline 3. Tytanit & 6.3 & 6.4 & 7.1 & 6.6 \\
\hline 4. GreenOK & 6.4 & 6.2 & 7.2 & 6.6 \\
\hline 5. BrunatneBio Złoto & 6.5 & 6.8 & 7.3 & 6.9 \\
\hline Mean & $\begin{array}{l}6.3 \\
\text { Jelly }\end{array}$ & 6.3 & 7.0 & $6.5 b$ \\
\hline 1. Control variant & 7.4 & 7.6 & 8.0 & 7.7 \\
\hline 2. Kelpak SL & 7.7 & 7.9 & 8.1 & 7.9 \\
\hline 3. Tytanit & 7.7 & 8.0 & 8.2 & 8.0 \\
\hline 4. GreenOk & 7.8 & 7.8 & 8.2 & 7.9 \\
\hline 5. BrunatneBio Złoto & 7.8 & 8.1 & 8.4 & 8.1 \\
\hline \multirow[t]{2}{*}{ Mean } & 7.7 & 7.9 & 8.2 & 7.9a \\
\hline & Tajfun & & & \\
\hline 1. Control variant & 6.5 & 6.0 & 6.9 & 6.5 \\
\hline 2. Kelpak SL & 6.6 & 6.4 & 7.1 & 6.7 \\
\hline 3. Tytanit & 6.8 & 6.5 & 7.3 & 6.9 \\
\hline 4. GreenOk & 6.6 & 6.6 & 7.5 & 6.9 \\
\hline 5. BrunatneBio Złoto & 6.8 & 6.5 & 7.6 & 7.0 \\
\hline \multirow[t]{2}{*}{ Mean } & 6.7 & 6.4 & 7.3 & $6.8 \mathrm{~b}$ \\
\hline & Mean for var & & & \\
\hline 1. Control variant & 6.6 & 6.5 & 7.2 & $6.8 \mathrm{~b}$ \\
\hline 2. Kelpak Sl & 6.9 & 6.8 & 7.4 & $7.0 \mathrm{ab}$ \\
\hline 3. Tytanit & 6.9 & 7.0 & 7.7 & $7.2 \mathrm{a}$ \\
\hline 4. GreenOk & 6.9 & 6.9 & 7.7 & $7.2 \mathrm{a}$ \\
\hline 5. BrunatneBio Złoto & 7.0 & 7.1 & 7.7 & $7.3 \mathrm{a}$ \\
\hline Mean & $6.9 a$ & $6.9 \mathrm{a}$ & $7.5 \mathrm{~b}$ & 7.1 \\
\hline
\end{tabular}

Means with the same letters do not differ significantly at $\mathrm{P} \leq 0.05$

Tubers harvested in 2016 had a significantly lower content of dry matter, and the lowest content was recorded in the growing season of 2015, during a particularly humid July and extremely dry August, so the rainfall was unevenly distributed. In addition, August was much cooler than it was for the multi-year period and there were large fluctuations in temperature in individual decades of the month (Tab. 2). The starch yield in 2015 and 2016 were at the same level (Tab. 3). The statistical calculations showed the significance of the interaction of years with potato varieties: years of using biostimulators, the varieties on which biostimulators were applied. The tested biostimulators influenced the dry matter yield from potato tubers during the years of research in various ways, as evidenced by the years $\mathrm{x}$ varieties interaction. The highest dry matter yield was produced by tubers harvested in 2017, sprayed with the BrunatneBio Złoto biostimulator. The impact of biostimulators on the yield of dry matter depended on meteorological conditions and the genetic factor (Tab. 2). According to Wierzbicka (2012), Zgórska and Grudzińska (2012), the concentration of dry matter and starch in potato tubers depends mainly 
on the genetic features of the varieties, but it can be modified by agrotechnology, as well as by weather and soil conditions. Research carried out by Keutgen et al. (2014), showed that the yield of dry matter is significantly influenced by genetic features. Different results were obtained by Krzysztofik and Skonieczny (2010), who observed that the early varieties were characterized by a lower content of dry matter and starch as compared with the medium-early varieties. This was confirmed by the results of Wszelaczyńska et al. (2014). In tests involving the use of biostimulators, an increase in dry matter yield in potato tubers has been observed (Sawicka and Krochmal-Marczak 2009). Many authors (Gugała et al. 2008, Mazurczyk et al. 2009, Gugała and Zarzecka 2010) emphasize that in the years with an even distribution of rainfall and temperature, dry matter content was higher than in the years with extreme weather conditions. According to Kołodziejczyk and Szmigla (2012), and also Wierzbicka (2012), years of cool and humid weather conditions reduced the content of dry matter and starch, while years of low precipitation, high temperatures, and high insolation during the growing season favoured their accumulation.

\section{CONCLUSIONS}

1. As a result of using biostimulators, the yield of dry matter and starch increased as compared to the control variant, the largest increase of these components was in tubers harvested from plots sprayed with the biostimulator BrunatneBio Złoto (variant 5).

2. The highest dry matter yield and starch yield was produced by the Jelly variety, the lowest by the Honorata variety

3. Diverse climatic conditions prevailing during the growing season in the years when the research was conducted, influenced the yield of dry matter and starch. The most favourable climatic conditions were observed in the third year of research.

\section{REFERENCES}

Barbaś P., Sawicka B., 2016. The effect of weeding methods on the content and yield of dry matter and starch in tubers of two potato varieties. Fragm. Agron., 33(4), 7-17.

Bienia B., Sawicka B., Krochmal-Marczak B., 2018. Influence of foliar fertilization with macro- and microelement fertilizers on the yield and yield structure of several potato varieties. Fragm. Agron., 35(1), 17-28.

Boguszewska D., Czerko Z., Goliszewski W., Grudzińska M., Lutomirska B., Nowacki W., Szutkowska M., Trawczyński C., Wierzbicka A., Zarzyńska K., Zgórska K., 2011. Characteristics of the National Register of Potato Varieties. Nowacki W. (Ed.) Wyd. IHAR-PIB, Oddział Jadwisin, 1-40.

Budzyński, W., Dubis, B., Jankowski, A., 2008. Response of Winter oilseed rape to the biostimulator Asahi SL applied in spring. Monographs series: Biostimulators in modern agriculture, Field Crop. Wieś Jutra, 47-55. 
Czeczko, R., Mikos-Bielak, M., 2004. Effects of Asahi bio-stimulator application in the cultivation of different vegetable species. Ann. UMCS, Agric., 59(3), 1073-1079.

Fageria N.K., Filho B.M.P., Moreira A., Guimarăes C.M., 2009. Foliar fertilization of crop plants. J. Plant Nutrition 32, 1044-1064, https://doi.org/10.1080/01904160902872826

Fernandez V., Sotiropoulos T., Brown P., 2013. Foliar fertilization. Scientific, principles and field practices. International Fertilizer Industry Association (IFA). Paris, France, ss: 144

Gugała M., Zarzecka K., Baranowska A., 2008. The influence of soil cultivation and methods of weeding on yield of nutrients and economic efficiency of potato cultivation. Vol. I. Potato nutrient yield. Acta Sci. Pol., Agricultura, 7(2), 21-31.

Gugała M., Zarzecka K., Sikorska A., Mystkowska I., Dołęga H., 2017. The effect of herbicides and growth biostimulators on reducing weed infestation and yielding of edible potato. Fragm. Agron., 34(4), 59-66.

Gugała M., Zarzecka K., 2010. The effect of adjuvants on yielding and limitation of weeds on potato plantations. Biul. IHAR, 255, 47-57.

Harasimowicz-Herman, G., Borowska, M., 2006. The effects of the Asahi SL biostimulator in the cultivation of winter oilseed rape depending on the pluvio-thermal conditions. Rośliny Oleiste XXVII(1), 95-106.

Keutgen A.J., Pobereżny J., Wszelaczyńska E., Murawska B., Spychaj-Fabisiak E., 2014. The influence of storage on darkening processes of potato tubers (Solanum tuberosum L.) and their pro-health properties. Inż. Ap. Chem., 53(2), 086-088.

Kołodziejczyk M., Szmigiel A., 2012. Chemical composition and selected quality parameters of potato tubers depending on the date and degree of reduction of plant assimilation area. Fragm. Agron., 29(3), 88-94.

Krzysztofik B., 2009. The effect of soil cultivation on the level of potato tuber size uniformity and starch yield. Acta Agroph. 14(2), 355-365.

Maciejewski T., Szukała J., Jarosz A., 2007. The impact of the Asahi SL biostimulator on the quality characteristics of potato tubers. J. Res. Appl. Agric. Eng., 52(3), 109-112.

Mazurczyk W., Wierzbicka A., Trawczyński C., 2009. Harvest index of potato crop grown under different nitrogen and water supply. Acta Sci. Pol., Agricultura, 8(4), 15-21.

Mystkowska I., 2018. Biostimulators as a factor affecting the yield of edible potato. Acta Agroph., 25(3), 307-315, https://doi.org/10.31545/aagr/95109

Pszczółkowski P., Sawicka B., 2018. The effect of application of biopreparations and fungicides on the yield and selected parameters of seed value of seed potatoes. Acta Agroph., 25(2), 239-255, https://doi.org/10.31545/aagr/93104

Sawicka B., Krochmal-Marczak B., 2009. The effects of combined use of foliar fertilizers and growth bioregulators in the cultivation of new potato varieties. Annales UMCS, E-64(2), 29-38, https://doi.org/10.2478/v10081-009-0015-z

Sawicka B., Pszczółkowski P., 2017. The phenotypic variability of the yield and its structure of very early and early potato varieties. Fragm. Agron., 34(1), 76-91.

Singh J., Singh M., Jain A., Bhardwaj S., Singh A., Singh D.K., Bhushan B., Dubey S.K. 2013. An introduction of plant nutrients and foliar fertilization: a review. In: Precision farming: a new approach. Daya Publishing Company. New Delhi, 252-320.

Trętowski, J., Wójcik, R., 1988. Methodology of agricultural experience. Wyd. WSRP, Siedlce, $1-500$.

Wierzbicka A., 2012. Influence of cultivar, nitrogen fertilization and harvesting time on dry matter and starch content in early potato tubers. Fragm. Agron., 29(2), 134-142. 
Wszelaczyńska E., Pobereżny J., Gruszczewski M., 2014. Storage stability and stability of qualitative features of selected potato varieties with different directions of use. Inż. Ap. Chem., 53(2), 127-129.

Zgórska K., Grudzińska M., 2012. Changes in selected quality traits of potato tubers during storage. Acta Agroph., 19(1), 203-214.

Żołnowski A.C., 2013. Studies on variability of yield and quality of edible potato (Solanum tuberosum L.) under conditions of differentiated mineral fertilization. 2013 UWM Olsztyn (Rozprawy i monografie - Dissertations and Monographs), 191, ss. 259. 